\title{
Upaya Ekstrakurikuler Kerohanian Islam (ROHIS) dalam Meningkatkan Sikap Keberagamaan Siswa di SMK Ibnu Taimiyah Pekanbaru
}

\author{
ALI NOER* \\ SYAHRAINI TAMBAK** \\ HARUN RAHMAN*** \\ *Fakultas Agama Islam (FAI) Universitas Islam Riau (UIR) Pekanbaru \\ Jl. Kaharuddin Nasution, No. 113, Perhentian Marpoyan Pekanbaru 28284 \\ e-mail: syahraini_tambak@yahoo.co.id \\ **Fakultas Agama Islam (FAI) Universitas Islam Riau (UIR) Pekanbaru \\ Jl. Kaharuddin Nasution, No. 113, Perhentian Marpoyan Pekanbaru 28284 \\ ***Fakultas Agama Islam (FAI) Universitas Islam Riau (UIR) Pekanbaru \\ Jl. Kaharuddin Nasution, No. 113, Perhentian Marpoyan Pekanbaru 28284
}

\begin{abstract}
Abstrak: Agama juga memiliki peran yang sangat penting dalam menentukan sikap dan perilaku seseorang. Sikap dan perilaku seseorang dapat dilihat dari cara seseorang tersebut menjalani kehidupannya sehari-hari. Rendahnya sikap keagamaan siswa di sekolah dikarenakan banyaknya budaya asing yang berpengaruh buruk terhadap perkembangan sikap keagamaan siswa. Salah satu contohnya adalah siswa sering berbohong kepada guru, tidak mengerjakan tugas, dan berkata yang tidak sopan. Banyaknya penyimpangan sikap keagamaan yang dilakukan oleh siswa pada umumnya yang tidak sesuai dengan norma agama akhir-akhir ini mendorong berbagai pihak mempertanyakan efektivitas pelaksanaan PAI di sekolah. Realitas sikap keberagamaan siswa di SMK Ibnu Taimiyah Pekanbaru mengalami kemunduran, ini dapat terlihat dari sikap siswa yang tidak sesuai dengan nilai-nilai agama. Bentuk usaha yang dilakukan sekolah dalam meningkatkan sikap keberagamaan siswa adalah dengan memberikan wadah Kerohanian Islam (ROHIS). Dari gejala tersebut penulis merumuskan masalah penelitian ini adalah : Bagaimana Upaya Ekstrakurikuler Kerohanian Islam (Rohis) Dalam Meningkatkan Sikap Keberagamaan Siswa Di SMK Ibnu Taimiyah Pekanbaru? Untuk memperoleh data dari penelitian ini, maka digunakan teknik pengumpulan data berupa angket yang disebarkan kepada siswa sebanyak 30 sampel, dan teknik analisis data yang digunakan ini bersifat deskriptif. Setelah dilaksanakan penelitian dan data yang terkumpul di olah dan di analisis maka diperoleh hasil persentase sebesar 82,25 \%. Hasil penelitian ini menunjukkan bahwa Upaya Ekstrakurikuler Kerohanian Islam (Rohis) Dalam Meningkatkan Sikap Keberagamaan Siswa Di SMK Ibnu Taimiyah Pekanbaru mengalami peningkatan dengan taraf tinggi.
\end{abstract}

Kata kunci : Ekstrakurikuler Kerohanian Islam (Rohis), sikap keberagaman 


\section{PENDAHULUAN}

Pendidikan Agama Islam (PAI) sangatlah penting bagi generasi muda. Hal ini dikarenakan bahwa agama merupakan salah satu pedoman hidup manusia di muka bumi. Agama juga memiliki peran yang sangat penting dalam menentukan sikap dan perilaku seseorang. Sikap dan perilaku seseorang dapat dilihat dari cara seseorang tersebut menjalani kehidupannya sehari-hari. Apabila seseorang menjalani kehidupannya berdasarkan Al-Qur'an dan Hadist sesuai perintah Allah SWT, maka seseorang tersebut telah dapat dikatakan memiliki sikap keagamaan yang baik. Allah SWT berfirman:

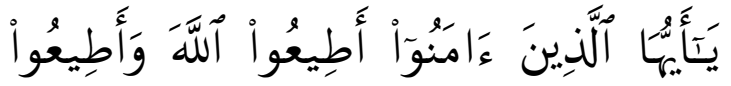
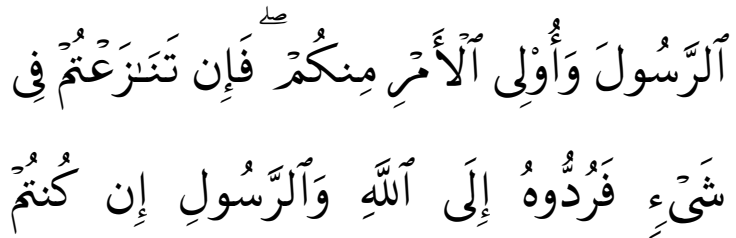

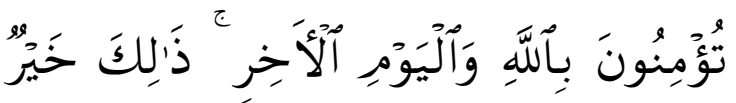

$$
\text { وَأَحَسَنُ تَأُويلاً }
$$

Artinya : " Hai orang-orang yang beriman, taatilah Allah dan taatilah Rasul (Nya), dan ulil amri diantara kamu. Kemudian jika kamu berlainan pendapat tentang sesuatu maka kembalikanlah ia kepada Allah (Al-Qur'an) dan rasul (sunnahnya), jika kamu benar-benar beriman kepada Allah dan hari kemudian. Yang demikian itu lebih utama (bagimu) dan lebih baik akibatnya".(QS. An-Nisaa', 4: 59).

Namun, pada masa sekarang banyak terjadinya penyimpangan sikap keagamaan yang dilakukan oleh generasi muda terlebih lagi yang dilakukan oleh para siswa di sekolah. Tentu saja penyimpangan yang dilakukan oleh siswa tersebut adalah suatu dosa, sebagaimana firman Allah SWT :

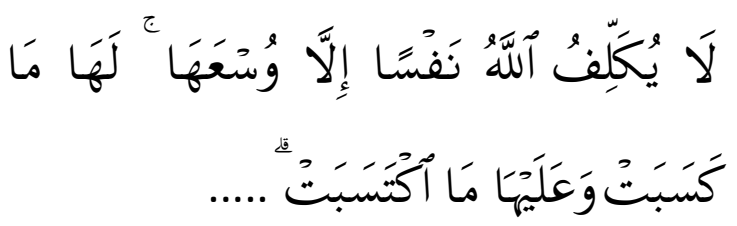

Artinya : " Ia mendapatkan pahala dari kebajikan yang telah diusahakannya, dan ia akan mendapat siksa dari kejahatan yang telah dikerjakannya" (QS. Al-Baqarah, 2: 286). Allah SWT juga berfirman :

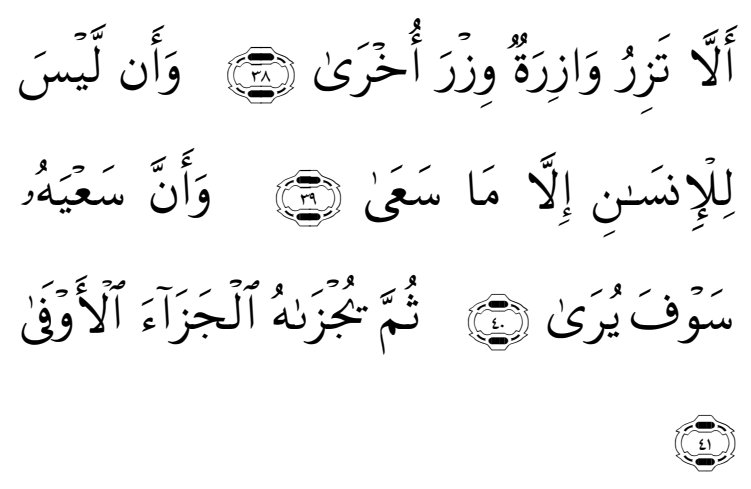

Artinya :" Bahwasanya seorang yang berdosa, tidak akan memikul dosa orang lain. Dan bahwasanya seseorang manusia tidak akan memperoleh selain apa yang telah diusahakannya. Dan bahwasanya usahanya itu kelak akan diperlihatkan (kepadanya). Kemudian akan diberi balasan kepadanya dengan balasan yang paling sempurna ". (QS. An-Najm, 53: $38-41)$.

Selain itu Rasulullah SAW bersabda: “ 


$$
\text { كلكم راع وكلكم مسؤل عن رعيته (رواه البخا }
$$

Artinya: "Semua kamu adalah pemimpin dan setiap kamu bertanggung jawab atas yang dipimpin." $(\mathrm{H}$. R. Bukhari).

Rendahnya sikap keagamaan siswa di sekolah dikarenakan banyaknya budaya asing yang berpengaruh buruk terhadap perkembangan sikap keagamaan siswa. Salah satu contohnya adalah siswa sering berbohong kepada guru, tidak mengerjakan tugas, dan berkata yang tidak sopan. Banyaknya penyimpangan sikap keagamaanyang dilakukan oleh siswa pada umumnya yang tidak sesuai dengan norma agama akhir-akhir ini mendorong berbagai pihak mempertanyakan efektivitas pelaksanaan PAI di sekolah.

Berdasarkan observasi awal yang penulis lakukan di Sekolah Menengah Kejuruan (SMK) Ibnu Taimiyah Pekanbaru ditemukan bahwa pembelajaran PAI yang hanya 2 jam dalam seminggu belumlah efektif. Sebagian siswa lebih terfokus pada pengembangan kemampuan kognitif dan minim dalam pembentukan sikap (afektif), pembiasaan dan pengamalan ajaran agama dalam kehidupan (psikomotor). Selain itu, indikasi adanya perilaku peserta didik yang mengarah pada religiousculture dan kontras dengan deskripsi remaja umumnya di SMK Ibnu Taimiyah Pekanbaru. Hal ini memperkuat alasan penulis untuk menjadikan SMK Ibnu Taimiyah Pekanbaru sebagai obyek yang layak diteliti.

Realitas sikap keberagamaan siswa di SMK Ibnu Taimiyah Pekanbaru mengalami kemunduran, ini dapat terlihat dari sikap siswa yang tidak sesuai dengan nilai-nilai agama antara lain: siswa sering lalai melaksanakan kewajibannya kepada Allah swt terutama shalat, mengucapkan kata- kata kasar dan jorok dalam pergaulan dengan temannya, pada saat bertemu dengan guru siswa enggan mengucapkan salam terutama kepada guru yang tidak mengajar di kelasnya. Sikap keberagamaan yang dikaji dalam penelitian ini adalah berkaitan dengan dimensi atau pokok-pokok Islam yang secara garis besar dibagi menjadi tiga yaitu Aqidah, Ibadah atau praktik agama (Syari'ah), dan Akhlak. Sikap keberagamaan bermacam-macam nilainya tergantung pada pelaksanaan dari setiap manusia itu sendiri. Hal ini tercermin pula dalam pendidikan nasional yaitu untuk berkembangnya potensi peserta didik agar menjadi manusia yang beriman dan bertakwa kepada Tuhan Yang Maha Esa, berakhlak mulia, sehat, berilmu, cakap, kreatif, mandiri dan menjadi warga negara yang demokratis serta bertanggung jawab.

Bentuk usaha yang dilakukan sekolah dalam meningkatkan sikap keberagamaan siswa adalah dengan memberikan wadah Kerohanian Islam (ROHIS). Ekstrakurikuler Rohis merupakan salah satu dari ekstrakurikuler yang menjadi suatu kegiatan yang berbasiskan agama. Dalam kegiatan ekstrakurikuler ini terdapat program-program yang diusahakan dapat menciptakan dan membangun sikap keberagamaan siswa diantaranya adalah pengajian, bakti sosial, pesantren kilat, peringatan hari besar Islam (PHBI), seni baca al-Qur'an, praktik pengamalan ibadah dan kreasi remaja muslim. Kegiatan keagamaanpun berjalan dengan didasari sikap toleransi antar umat beragama. Bahkan menurut Muhaimin (2009 : 59), diperlukan pula kerjasama yang harmonis dan interaktif diantara para warga sekolah dan para tenaga kependidikan yang ada didalamnya. Dengan adanya kerjasama seluruh komponen di sekolah, diharapkan akan 
melahirkan suatu budaya sekolah yang kuat dan bermutu.

Ekstrakurikuler Rohis sebagai suatu wadah keagamaan yang bergerak secara independen di mana wadah tersebut dikelola dan dikembangkan oleh siswa serta pembina Rohis, sehingga secara struktural dan operasionalnya sudah dapat dikatakan sebagai suatu lembaga yang mempunyai kepengurusan, tujuan yang hendak dicapai secara jelas dan dapat memberikan dukungan terhadap pelajaran agama Islam. Dalam upaya meningkatkan mutu pendidikan, PAI harus dijadikan tolak ukur dalam membentuk watak dan pribadi peserta didik, serta membangun moral bangsa (Alim, 2006 : 8).

Setiap kegiatan di sekolah khususnya ekstrakurikuler rohis tentu memberikan dampak kepada proses pembelajaran ataupun kepada siswanya. Baik itu dampak positif ataupun dampak negatif. Adapun dampak positif dari ekstrakurikuler terhadap prestasi belajar siswa, yaitu : memberikan wawasan akademik maupun non akademik, membentuk karakter siswa, membentuk sikap siswa, mengembangkan bakat siswa, menunjang prestasi belajar siswa. Selain memiliki dampak positif, ekstrakurikuler juga berdampak negatif bagi proses pembelajaram. Dampak negatif tersebut diantaranya : mengurangi waktu belajar siswa baik di rumah maupun di sekolah, sangat menguras stamina para siswa karena waktu istirahat mereka digunakan untuk kegiatan ekstrakurikuler, Terkadang mengganggu kegiatan belajar siswa di kelas.

Berdasarkan hasil wawancara peneliti dengan Ibu Jeni Hariani selaku pembimbing Rohis di SMK Ibnu Taimiyah Pekanbaru diketahui bahwa hanya sebagian kecil siswa yang mengikuti kegiatan Rohis. Banyak kendala yang ada dalam mengembangkan ekstrakurikuler Rohis di sekolah ini, yaitu kurang minat siswa, kurangnya dorongan orang tua, dan ada beberapa siswa yang tidak bisa membaca Al-Qur'an. Para siswa berfikir jika ingin mengikuti kegiatan Rohis harus lancar membaca Al-Qur'an, sehingga membuat mereka malu untuk belajar dan dilihat oleh teman-teman yang lain. Selain itu siswa juga seringkali bersikap acuh tak acuh terhadap ajaran agama islam.

Sebagian siswa yang mengikuti kegiatan ekstrakurikuler rohis ini dilatih dan dibimbing oleh pembina rohis agar dapat mengembangkan bakat, menambah keimanan dan memiliki sikap keagamaan yang sesuai dengan ajaran agama islam. Adapun kegiatan-kegiatan yang dilakukan dalam usaha meningkatkan sikap keagamaan siswa salah satunya adalah dengan cara membimbing siswa dalam pergaulan sehari-hari, baik itu bergaul dengan teman sepermainan atupun dengan orang yang lebih tua. Siswa juga diberitahu bahwa Allah SWT adalah Maha Melihat dan Maha Mendengar, sehingga siswa diharapkan dapat mengendalikan ucapan dan tindakannya sehingga menjadi kebiasaan yang baik dan akan tebentuklah sikap yang sesuai dengan ajaran agama islam. Sikap yang demikian disebut sikap keagamaan.

Berdasarkan latar belakang masalah yang telah dikemukakan, maka penulis membatasi masalah yaitu "Upaya Ekstrakurikuler Kerohanian Islam (Rohis) Dalam Meningkatkan Sikap Keberagamaan Siswa Di SMK Ibnu Taimiyah Pekanbaru". Berdasarkan pembatasan masalah tersebut, dirumuskan masalah pokok yang menjadi pertanyaan dalam penelitian berikut ini : "Bagaimana Upaya Ekstrakurikuler Kerohanian Islam (Rohis) Dalam Meningkatkan Sikap 
Keberagamaan Siswa Di SMK Ibnu Taimiyah Pekanbaru?" Sejalan dengan perumusan masalah tersebut maka yang menjadi tujuan dalam penelitian ini adalah untuk mengetahui Upaya Ekstrakurikuler Kerohanian Islam (Rohis) Dalam Meningkatkan Sikap Keberagamaan Siswa Di SMK Ibnu Taimiyah Pekanbaru.

\section{KONSEP TEORI}

\section{Hakikat Kegiatan Ekstrakurikuler Rohani Islam (Rohis)}

Berbagai referensi mengenai kegiatan ekstrakurikuler diantaranya adalah menurut Permen Nomor 62 Tahun 2014 yang menjelaskan bahwa kegiatan ekstrakurikuler adalah kegiatan kurikuler yang dilakukan oleh peserta didik di luar jam belajar kegiatan intrakurikuler dan kegiatan kokurikuler, di bawah bimbingan dan pengawasan satuan pendidikan.

Kegiatan ekstrakurikuler merupakan kegiatan pengayaan dan perbaikan yang berkaitan dengan program kokurikuler dan intrakurikuler. Kegiatan ini dapat dijadikan sebagai wadah bagi siswa yang memiliki minat mengikuti kegiatan tersebut. Melalui bimbingan dan pelatihan guru, kegiatan ekstrakurikuler dapat membentuk sikap positif terhadap kegiatan yang diikuti oleh para siswa. Kegiatan ekstrakurikuler yang diikuti dan dilaksanakan oleh siswa baik di sekolah maupun di luar sekolah, bertujuan agar siswa dapat memperkaya dan memperluas diri. Memperluas diri ini dapat dilakukan dengan memperluas wawasan pengetahuan dan mendorong pembinaan sikap atau nilai-nilai.

Selanjutnya menurut Kamus Besar Bahasa Indonesia yaitu:"suatu kegiatan yang berada di luar program yang tertulis di dalam kurikulum seperti latihan kepemimpinan dan pembinaan siswa" (Departemen Pendidikan Nasional, 2008 :360). Kegiatan ekstrakurikuler sendiri dilaksanakan diluar jam pelajaran wajib. Kegiatan ini memberi keleluasaan waktu dan memberikan kebebasan pada siswa, terutama dalam menentukan jenis kegiatan yang sesuai dengan bakat serta minat mereka.

Pengertian ekstrakurikuler yaitu: suatu kegiatan yang diselenggarakan diluar jam pelajaran biasa dalam suatu susunan program pengajaran, disamping untuk lebih mengaitkan antara pengetahuan yang diperoleh dalam program kurikulum demgan keadaan dan kebutuhan lingkungan, juga untuk pengayaan wawasan dan sebagai upaya pemantapan kepribadian (Zainal Aqib \& Sujak, 2011: 81).

Ekstrakurikuler merupakan kegiatan yang menekankan kepada kebutuhan siswa agar menambah wawasan, sikap dan keterampilan siswa baik diluar jam pelajaran wajib serta kegiatannya dilakukan di dalam dan di luar sekolah. Dengan demikian dapat disimpulkan bahwa kegiatan ekstrakurikuler merupakan sebuah upaya untuk melengkapi kegiatan kurikuler yang berada diluar jam pelajaran yang dilakukan di dalam lingkungan sekolah maupun di luar lingkungan sekolah guna melengkapi pembinaan manusia seutuhnya dalam hal pembentukan kepribadian para siswa.

Rohis merupakan singkatan dari kerohanian Islam yang merupakan sebuah organisasi guna memperdalam dan memperkuat ajaran agama Islam. Menurut Kamus Besar Bahasa Indonesia Kerohanian Islam berasal dari kata dasar "Rohani" yang mendapat awalan ke- dan akhiran -an yang berarti hal-hal tentang rohani, dan "Islam" adalah mengikrarkan dengan lidah dan membenarkan dengan hati serta mengerjakan dengan sempurna oleh 
anggota tubuh dan menyerahkan diri kepada Allah swt dalam segala ketetapanNya dan dengan segala qadha dan qadarNya (Departemen Pendidikan Nasional : 2008).

Berdasarkan uraian tersebut dapat disimpulkan bahwa ekstrakurikuler Rohis adalah sekumpulan orang-orang atau kelompok orang atau wadah tertentu dan untuk mencapai tujuan atau cita-cita yang sama dalam badan kerohanian sehingga manusia yang tergabung di dalamnya dapat mengembangkan diri berdasarkan konsep nilai-nilai keislaman dan mendapatkan siraman kerohanian.

Fungsi Rohis adalah forum, pengajaran, dakwah, dan berbagi pengetahuan Islam. Susunan dalam Rohis layaknya organisasi OSIS, di dalamnya terdapat ketua, wakil, bendahara, sekretaris, dan divisi-divisi yang bertugas pada bagiannya masingmasing. Ekstrakurikuler ini juga memiliki program kerja serta anggaran dasar dan anggaran rumah tangga. Rohis mampu membantu mengembangkan ilmu tentang Islam yang diajarkan di sekolah.

Kegiatan ekstrakurikuler tidak terbatas pada program untuk membantu ketercapaian tujuan kurikuler saja, tetapi juga mencakup pemantapan dan pembentukan kepribadian yang utuh termasuk pengembangan minat dan bakat peserta didik. Dengan demikian program kegiatan ekstrakurikuler harus di rancang sedemikian rupa sehingga dapat menunjang kegiatan kurikuler, maupun pembentukan kepribadian yang menjadi inti kegiatan ekstrakurikuler.

Adapun tujuan ekstrakurikuler Rohis menurut Handani adalah sebagai berikut: (1) Membantu individu mewujudkan dirinya menjadi manusia seutuhnya agar mencapai kebahagiaan hidup di dunia dan di akhirat; (2)
Memberikan pertolongan kepada setiap individu agar sehat secara jasmaniah dan rohaniah; (3) Meningkatkan kualitas keimanan, ke-Islaman, keihsanan dan ketauhidan dalam kehidupan sehari-hari dan nyata; (4) Mengantarkan individu mengenal, mencintai dan berjumpa dengan esensi diri dan citra diri serta dzat yang Maha Suci yaitu Allah SWT; (5) Membantu individu agar terhindar dari masalah; (6) Membantu individu mengatasi masalah yang sedang dihadapinya; dan (7) Membantu individu memelihara dan mengembangkan situasi dan kondisi yang baik atau yang telah baik agar tetap baik atau menjadi lebih baik, sehingga tidak akan menjadi sumber masalah bagi dirinya dan orang lain (Handani, 2002 : 18)

Bagaimanapun tujuan bimbingan rohani Islam adalah untuk menuntun seseorang dalam rangka memelihara dan meningkatkan kualitas keagamaannya baik ibadah mahdhah maupun ghairu mahdhah. Dari sisi ini dapat dikatakan bahwa tujuan program kegiatan ekstrakurikuler adalah untuk memperdalam dan memperluas pengetahuan peserta didik, mengenal hubungan antar berbagai mata pelajaran, menyalurkan bakat dan minat, serta melengkapi upaya pembinaan manusia seutuhnya.

Di sisi lain, pembinaan manusia seutuhnya dalam kegiatan ekstrakurikuler yang dilakukan di sekolah maupun di luar sekolah diharapkan mampu mendorong pembinaan sikap dan nilai-nilai dalam rangka penerapan pengetahuan dan kemampuan yang telah dipelajari dari berbagai mata pelajaran dalam kurikulum.

Berdasarkan uraian di atas, dapat ditegaskan bahwa tujuan kegiatan ekstrakurikuler Rohis adalah untuk memperkaya dan memperluas wawasan pengetahuan, pembinaan 
sikap dan nilai serta kepribadian yang pada akhirnya bermuara pada penerapan akhlak mulia.

Adapun kegiatan-kegiatan Rohis adalah sebagai berikut: (1) Pembelajaran Islam lewat metode kelompok setiap minggu; (2) Pembelajaran Islam di alam terbuka; (3) Malam bina iman dan takwa (mabit); (4) Baca tulis Alquran (BTA); (5) Perbaikan bacaan Alquran dengan tajwid aplikatif (tahsin); Penghafalan Alquran sehari 1 ayat; (7) Pelatihan motivasi untuk menyeimbangkan kecerdasan intelektual, kecerdasan spiritual, dan kecerdasan emosional; dan (8) Kelompok belajar untuk mencetak muslim berprestasi (wikipedia, diakses 5 April 2016).

\section{Hakikat Sikap Keberagamaan}

La Pierre (1934) mendefinisikan sikap sebagai suatu pola perilaku, tendensi atau kesiapan antisipatif, predisposisi untuk menyesuaikan diri dalam situasi sosial, atau secara sederhana sikap adalah respons terhadap stimuli sosial yang telah terkondisikan (Saifuddin, 1995 : 5).

Sikap atau attitude adalah suatu cara bereaksi terhadap suatu perangsang, suatu kecenderungan untuk bereaksi dengan cara tertentu terhadap suatu perangsang atau situasi yang dihadapi (M. Ngalim Purwanto, 2007 : 141).

Sikap pada hakikatnya adalah kecendrungan berperilaku pada seseorang. Sikap juga dapat diartikan reaksi seseorang terhadap suatu stimulus yang datang kepada dirinya (Sudjana, 2005 : 80).

Menurut oemar hamalik, sikap merupakan tingkat efektif yang positif atau negatif yang berhubungan dengan objek psikologis positif dapat diartikan senang, sedangkan negatif berarti tidak senang atau menolak. Pernyataan tersebut menunjukkan bahwa, pada prinsipnya sikap adalah kecendrungan individu terhadap suatu bertindak dengan cara tertentu, apakah dalam bentuk kecendrungannya untuk berperilaku dalam bentuk menerima, maka mereka menghayati serta mencintai dan selalu ingin berbuat, atau kecendrungan untuk membenci maka ia akan menolak, dan selalu untuk menghindari. Sebagai reaksi, maka sikap selalu berhubungan dalam dua hal yaitu rasa senang (like) atau tidak senang (dislike), menurut dan melaksanakan atau menjauhi dan menghindari sesuaatu. Dengan demikian sikap pula bersifat positif dan dapat pula bersifat negatif (Ramayulis, $2002: 110$ ).

Pada esensi sikap terdapat tiga komponen yang berkerja pada kompleks, yang merupakan bagian yang sangat menentukan sikap seseorang terhadap suatu obyek baik berupa kongkret maupun absarak,yaitu: (1) komponen kognisi akan menjawab tentang apa yang dipikirkan atau dipersepsikan tentang obyek, (2) komponen afikasi dikaitkan dengan apa yang dirasakan terhadap obyek (senang atau tidak senang), dan (3) komponen konasi berhubungan dengan kesediaan dan kesiapan untuk bertindak terhadap objek. Sebagai suatu sistem, ketiga komponen sikap tersebut antara satu dengan yang lainnya saling bergubungan dan pengaruh mempengaruhi (Ramayulis , 2002 : 110).

Dengan melihat komponen sikap tersebut, dapat dipahami bahwa manusia pada waktu lahir belum membawa sikap, dan sikap itu berbentuk dalam perkembangan individu. Hal ini berarti pula bahwa sikap dapat dipelajari dan dapat berubah-ubah. Sikap merupakan hasil belajar yang diperoleh melalui 
pengalaman dan interaksi dan komunikasi yang terus menerus dan lingkungan sekitarnya. Secara sadar atau tidak, individu memperhatikan objek yang ada disekitarnya dan menentukan sikap terhadap objek tersebut.

Berdasarkan penjelasan tersebut dapat disimpulkan bahwa sikap adalah suatu bentuk reaksi perasaan seseorang terhadap suatu obyek. Sikap itu berupa yang mendukung maupun perasaan tidak mendukung yang mempunyai tiga komponen yaitu kognisi, afikasi dan konasi.

Keagamaan berasal dari kata dasar agama. Kata "agama" dalam bahasa Indonesia berasal dari bahasa Sansekerta yang bermakna tradisi atau peraturan hidup atau sesuatu yang tidak bergerak atau tidak ada kekacauan (Subandi, 2013 : 25). Hal ini membuktikan bahwa agama memberikan berbagai aturan pada manusia yang diterapkan melalui tradisi kehidupan sehari-hari. Tradisi tersebut tidak akan berubah selamanya, sehingga membuat hidup manusia tidak kacau.

Harun Nasution merunut pengertian agama berdasarkan asal kata yaitu al-Din, religi (relegere, religare) dan agama. Al-din (semit) berarti undang-undang atau hukum. Kemudian dalam bahasa arab, kata ini mengandung arti menguasai, menundukkan, patuh, hutang, balasan kebiasaan. Sedangkan kata religi (latin) atau relegere berarti mengumpulkan dan membaca. Kemudian religare berarti mengikat. Adapun kata agama terdiri dari a = tidak ; gam = pergi mengandung arti tidak pergi, tetap ditempat atau diwarisi turun temurun (Jalaluddin, $2008:$ 12).

Bertitik dari tolak dari pengertian kata-kata tersebut menurut Harun Nasution, intisarinya adalah ikatan. Karena itu agama mengandung arti ikatan yang harus dipegang dan dipatuhi manusia. Ikatan dimaksud berasal dari suatu kekuatan yang lebih tinggi dari manusia sebagai kekuatan gaib yang tidak dapat ditangkap oleh pancaindera, namun pengaruh besar sekali terhadap kehidupan manusia sehari-hari.

Sedangkan menurut Robert $\mathrm{H}$. Thouless agama adalah sikap (cara penyesuaian diri) terhadap dunia yang mencakup acuan yang menunjukkan lingkungan lebih luas dari pada lingkuangan dunia fisik yang terikat ruang dan waktu (Jalaluddin, 2008:14).

Sebagian ahli studi keagamaan beranggapan bahwa kata "religion" berasal dari bahasa latin "religio" yang digunakan untuk menggambarkan keyakinan adanya kekuatan yang luar biasa yang berada di luar diri manusia.

Sikap keagamaan tidak terlepas dari keberadaan agama. Apabila terpola dalam pikiran bahwa agama itu sesuatu yang benar maka apa saja yang menyangkut dengan agama akan membawa makna positif. Kepercayaan bahwa agama itu adalah suatu yang benar mengambil bentuk perasaan positif terhadap agama. Menurut Abu Ahmadi yang dikutip oleh Ramayulis "apabila individu memiliki sikap positif terhadap suatu objek ia akan siap membantu memperhatikan, berbuat sesuatu yang menguntungkan objek itu". Bila seseorang percaya bahwa agama itu adalah sesuatu yang benar dan baik, maka timbullah perasaan cinta, suka, setuju, simpati dan menyenangkan serta mengalihkan sikap negatif, yaitu perasaan, antipati, menolak, mengecam, mencela, menyerang bahkan membinasakan. Perasaan seseorang mempengaruhi perilaku seseorang. Artinya bagaimana seseorang berperilaku terhadap suatu objek, banyak ditentukan sebagai oleh corak kepercayaan dan perasaan seseorang terhadap objek tersebut. 
Dengan demikian kecendrungan berprilaku keagamaan selaras dengan kepercayaan dan perasaan seseorang terhadap agama itu. Secara logika dapat dikatakan bahwa sikap seseorang akan tercermin dari perilakunya terhadap suatu objek.

Konsitensi antara kepercayaan terhadap agama sebagai komponen kognitif, perasaan terhadap agama sebagai komponen efektif, dengan perilaku terhadap agama sebagai komponen konasi menjadi landasan pembentukan sikap keagamaan adalah sikap seseorang yang ada kaitannya dengan keagamaan. Seperti dikemukakan diatas komponen konasi adalah semacam kecendrungan, kesediaan, kesiapan untuk berbuat, atau peroses perbuatan itu sendiri. Atau dengan kata lain komponen konasi adalah komponen yang berkaitan dengan tingkah laku (behavior) di dalam ajaran agama tingkah laku keagamaan itu disebut amal keagamaan.

Didalam sikap keberagamaan komponen-komponennya selalu berhubungan erat. Seorang yang melakukan amal keagamaan, karena ia terlebih dahulu sudah mengetahui dan meyakini bahwa agama itu baik dan benar, serta mempunyai perasan senang terhadap agama. Masing-masing komponen tidak bisa berdiri sendiri namun saling berinteraksi sesamanya secara kompleks.

Kecenderungan manusia untuk percaya adanya Allah SWT diwujudkan dengan melaksanakan segala yang diperintahkan dan menjahui segala apa yang dilarang-Nya. Pengabdian diri kepada Allah SWT itu akhirnya melahirkan adanya tingkah laku keagamaan. Fenomena dari tingkah laku keagamaan itu sangat luas sekali cakupannya. Ia bisa meliputi seluruh aspek kehidupan manusia. orang yang benar-benar berbakti kepada Allah
SWT, menghayati betul segala perintahNya dan melaksanakannya maka orang tersebut adalah orang yang taat beragama.

Ketaatan beragama membawa dampak positif terhadap kesehatan mental karena pengalaman membuktikan bawa seseorang yang taat beragama ia selalu mengingat Allah SWT, jiwa akan semakin tentram. sebagai mana dalam firman Allah: "Sesungguhnya dengan mengingat Allah jiwa akan tentram" (QS:13.28).

Dari uraian di atas dapat disimpulkan sikap keberagamaan adalah suatu keadaan diri seseorang dimana setiap melakukan atas aktivitasnya selalu bertautan dengan agamanya. Semua aktivitas yang dilakukan berdasarkan keyakinan hatinya yang dilandasi dengan keimanan.

\section{Pembentukan Sikap}

Sikap sosial terbentuk dari adanya interaksi sosial yang dilakukan oleh individu. Dalam interaksi sosial, terjadi hubungan yang saling mempengaruhi diantara individu yang satu dengan individu yang lainnya, terjadi hubungan timbal balik yang turut mempengaruhi pola perilaku masing-masing individu sebagai anggota masyarakat. Berdasarkan teori tersebut dapat disimpulkan bahwa terbentuknya sikap keagamaan juga dapat terbentuk dari adanya interaksi sosial yang dilakukan antar individu dalam organisasi keagamaan atau masyarakat. Organisasi keagamaan tingkat sekolah yang dapat diikuti oleh siswa salah satunya adalah ekstrakurikuler Rohis (Saifuddin, 1995 : 30).

Seseorang akan menampakkan sikapnya dikarenakan adanya pengaruh dari luar atau lingkungan. Manusia tidak dilahirkan dengan kelengkapan sikap, akan tetapi sikap-sikap itu lahir 
dan berkembang bersama dengan pengalaman yang diperolehnya. Jadi sikap bisa berkembang sebagaimana terjadi pada pola tingkah laku yang bersifat mental dan emosi lainnya, sebagai bentuk reaksi individu terhadap lingkungannya. Terbentuknya sikap melalui bermacam-macam cara, antara lain: (1) Melalui pengalaman yang berulang-ulang, atau dapat melalui suatu pengalaman yang disertai perasaan yang mendalam (pengalaman traumatik); (2) Melalui Imitasi. Peniruan dapat terjadi tanpa disengaja, dapat pula dengan sengaja. Individu harus mempunyai minat dan rasa kagum terhadap mode, disamping itu diperlukan pula pemahaman dan kemampuan untuk mengenal model yang hendak ditiru; (3) Melalui Sugesti. Seseorang membentuk suatu sikap terhadap objek tanpa suatu alasan dan pemikiran yang jelas, tapi semata-mata karena pengaruh yang datang dari seseorang atau sesuatu yang mempunyai wibawa dalam pandangannya; dan (4) Melalui Identifikasi. Disini seseorang meniru orang lain atau suatu organisasi tertentu didasari suatu keterikatan emosional sifatnya, meniru dalam hal ini lebih banyak dalam arti berusaha menyamai, identifikasi seperti siswa dengan guru (Slameto, 1995 : 189).

Dalam pembentukan sikap faktor pengalaman mempunyai peran yang sangat penting. Hal ini berarti sikap seseorang akan banyak dipengaruhi oleh lingkungan budaya, misalnya keluarga, norma, agama, adat istiadat. Namun dalam pembentukan sikap seseorang individu, faktor individu itu sendiri ikut pula menentukan. Dengan demikian faktor internal bersama faktor eksternal bersama-sama akan mempengaruhi terhadap pembentukan dan perubahan sikap seseorang. Menurut Siti Partini dalam Hanafi, faktor-faktor yang mempengaruhi pembentukan sikap adalah: (1) aktor internal; yakni faktor yang berasal dari dalam diri individu yaitu kemampuan menyeleksi dan mengolah atau menganalisis pengaruh yang datang dari luar, termasuk disini minat,perhatian,dan sebagainya; dan (2) faktor eksternal; faktor yang berasal dari luar individu yaitu pengaruh dari lingkungan yang diterimanya (Hanafi, $2014: 181)$.

\section{Faktor-faktor Pendukung dan Penghambat terbentuknya sikap keberagamaan}

Pembentukan sikap keberagamaan dipengaruhi oleh berbagai faktor baik faktor pendukung dan penghambat. Untuk lebih jelasnya penulis akan menguraikannya sebagai berikut: (1) Faktor pendukung terbentuknya sikap keagamaan, terdiri dari faktor internal dan faktor eksternal. Adapun faktor internal yaitu: (a) Kebutuhan manusia terhadap agama. Secara kejiwaan manusia memeluk kepercayaan terhadap sesuatu yang menguasai dirinya. Menurut Robert Nuttin, dorongan beragama merupakan salah satu dorongan yang ada dalam diri manusia, yang menuntut untuk dipenuhi sehingga pribadi manusia mendapat kepuasan dan ketenangan, selain itu dorongan beragama juga merupakan kebutuhan insaniyah yang tumbuhnya dari gabungan berbagai faktor penyebab yang bersumber dari rasa keagamaan (Jalaluddin, 2008 : 9798); dan (b) Adanya dorongan dalam diri manusia untuk taat, patuh dan mengabdi kepada Allah swt. Manusia memiliki unsur batin yang cenderung mendorongnya kepada zat yang ghaib, selain itu manusia memiliki potensi beragama yaitu berupa kecenderungan untuk bertauhid. Faktor ini disebut sebagai fitrah beragama yang dimiliki 
oleh semua manusia yang merupakan pemberian Tuhan untuk hambaNya agar mempunyai tujuan hidup yang jelas yaitu hidup yang sesuai dengan tujuan penciptaan manusia itu sendiri yakni menyembah (beribadah) kepada Allah. Melalui fitrah dan tujuan inilah manusia menganut agama yang kemudian diaktualisasikan dalam kehidupan dalam bentuk sikap keberagamaan.

Sedangkan faktor eksternal, yaitu: (a) Lingkungan keluarga. Kehidupan keluarga menjadi fase sosialisasi pertama bagi pembentukan sikap keberagamaan seseorang karena merupakan gambaran kehidupan sebelum mengenal kehidupan luar; dan (b) Lingkungan sekolah. Sekolah menjadi lanjutan dari pendidikan keluarga dan turut serta memberi pengaruh dalam perkembangan dan pembentukan sikap keberagamaan seseorang.

Selain itu, adapula faktor penghambat terbentuknya sikap keagamaan, yang juga terdiri dari faktor internal dan faktor eksternal. Dalam bukunya, Jalaluddin menjelaskan bahwa penyebab terhambatnya perkembangan sikap keberagamaan yang berasal dari dalam diri (faktor internal) adalah: (a) Tempramen adalah salah satu unsur yang membentuk kepribadian manusia dan dapat tercermin dari kehidupan kejiwaannya; (b) Gangguan jiwa. Orang yang mengalami gangguan jiwa akan menunjukkan kelainan dalam sikap dan tingkah lakunya; (c) Konflik dan keraguan. Konflik kejiwaan pada diri seseorang dalam hal keberagamaan akan mempengaruhi sikap seseorang akan agama seperti taat, fanatik atau agnostik sampai pada ateis (Jalaluddin, 2008 : 120-121); dan (d) Jauh dari Tuhan. Orang yang hidupnya jauh dari agama, dirinya akan merasa lemah dan kehilangan pegangan ketika mendapatkan cobaan dan hal ini dapat berpengaruh terhadap perubahan sikap keberagamaan pada dirinya.

Keadaan jiwa seseorang sangat berpengaruh dalam pembentukan sikap. Jiwa yang resah, penuh dengan konflik, keraguan bahkan kehilangan kepercayaan terhadap Tuhan sangat terhambat untuk terbentuknya sebuah sikap keberagamaan.

Sedangkan faktor eksternal yang menghambat terbentuknya sikap keagamaan, terdiri dari : (a) Lingkungan keluarga. Lingkungan keluarga yang dapat menghambat yaitu lingkungan keluarga yang di dalamnya tidak terdapat pendidikan agama khususnya dari orang tua. Hal ini dapat menghambat perkembangan sikap keberagamaan anak karena didikan dalam keluarga terutama pendidikan agama sangat berperan untuk perkembangan selanjutnya; dan (b) Lingkungan sekolah. Seperti lingkungan keluarga, lingkungan sekolah juga dapat menghambat pembentukan sikap keberagamaan seseorang. Misalnya: Siswa yang salah memilih teman di sekolah sehingga mereka terjerumus dalam pergaulan bebas (Zakiyah, 1994 : 84).

\section{Manfaat Sikap Keberagamaan Aspek Aqidah}

Manfaat sikap keberagamaan dalam aspek aqidah merupakan hal yang krusial, yaitu menambah kuatnya aqidah atau sebuah pemahaman. Dengan adanya sikap keberagamaan yang merupakan realisasi dari sebuah pemahaman maka akan terjadi keseimbangan yang baik antara ranah teoritis dengan ranah empiris.

\section{Aspek diri pribadi}

Manfaat sikap keberagamaan dalam kehidupan seseorang berpengaruh biasanya pada saat ia sudah mengerti 
atau dewasa. Dalam hal ini secara pribadi atau individual diri paham akan kesehatan sebagai anugrah dari Tuhan dan harus dijaga, dengan adanya sikap keberagamaan ia akan berpikir untuk tidak merusak kesehatan atau tubuhnya dengan melakukan hal-hal yang buruk sehingga mengakibatkan kerusakan atas tubuhnya, meningkatkan kualitas psikologi substansi psikologis (kejiwaan atau rohaniah).

\section{Aspek rasa tanggung jawab sosial}

Di dalam al-Qur'an dan Sunnah sudah terdapat prinsip -prinsip umum tentang pembinaan masyarakat yang harus kita jadikan landasan. Ada beberapa kaidah sosial atau prinsipprinsip kemasyarakatan yang perlu diperhatikan oleh manusia dalam menyusun konsepsi bagi masyarakat, bangsa dan negara (Mushbihah, 2013 : 39).

\section{Indikator Sikap Keberagamaan}

\section{Sejalan dengan tingkat}

perkembangan usianya, maka sikap keberagamaan pada orang dewasa memiliki ciri-ciri sebagai berikut: (1) Menerima kebenaran agama berdasarkan pertimbangan pemikiran yang matang, bukan sekedar ikutikutan; (2) Cenderung bersifat realitas, sehinggga norma-norma agama lebih banyak diaplikasikan dalam sikap dan tingkah laku; (3) Bersikap positif terhadap ajaran dan norma-norma agama, dan berusaha untuk mempelajari dan memperdalam pemahaman keagamaan; (4) Tingkat ketaatan beragama didasarkan atas pertimbangan dan tanggung jawab diri hingga sikap keberagamaan merupakan realisasi dari sikap hidup; (5) Bersikap lebih terbuka dan wawasan yang lebih luas; (6) Bersikap lebih kritis terhadap materi ajaran agama sehingga kemantapan beragama selain didasarkan atas pertimbangan pikiran, juga didasarkan atas pertimbangan hati nurani; (7) Sikap keberagamaan cenderung mengarah kepada tipe-tipe kepribadian masing-masing, sehingga terlihat adanya pengaruh kepribadian dalam menerima, memahami serta melaksanakan ajaran agama yang diyakininya; dan (8) Terlihat adanya hubungan antar sikap keberagamaan dengan kehidupan sosial sehingga perhatian terhadap kepentingan organisasi sosial keagamaan sudah berkembang (Hanafi, 2014 : 81).

Berdasarkan hal di atas dapat diketahui bahwa sikap keberagamaan itu merupakan keadaan di dalam diri seseorang yang mendorongnya untuk bertingkah laku sesuai dengan kadar ketaatannya terhadap agama. Sikap keberagamaan ini merupakan integrasi secara kompleks antara pengetahuan agama, perasaan agama serta tindak keagamaan dalam diri seseorang. Dalam hal ini dengan mengikuti kegiatan ektrakurikuler Rohis di sekolah merupakan salah satu cara untuk meningkatkan sikap keberagamaan siswa. Maka dalam penelitian ini dapat disimpulkan indikator sikap keberagaman adalah sebagai berikut : (1) Menerima kebenaran agama berdasarkan pertimbangan pemikiran yang matang, bukan sekedar ikutikutan; (2) Cenderung bersifat realitas, sehinggga norma-norma agama lebih banyak diaplikasikan dalam sikap dan tingkah laku; (3) Bersikap positif terhadap ajaran dan norma-norma agama, dan berusaha untuk mempelajari dan memperdalam pemahaman keagamaan; (4) Tingkat ketaatan beragama didasarkan atas pertimbangan dan tanggung jawab diri hingga sikap keberagamaan merupakan realisasi dari sikap hidup; (5) Bersikap lebih terbuka dan wawasan yang lebih luas; (6) Bersikap lebih kritis terhadap materi ajaran agama sehingga 
kemantapan beragama selain didasarkan atas pertimbangan pikiran, juga didasarkan atas pertimbangan hati nurani; (7) Sikap keberagamaan cenderung mengarah kepada tipe-tipe kepribadian masing-masing, sehingga terlihat adanya pengaruh kepribadian dalam menerima, memahami serta melaksanakan ajaran agama yang diyakininya; dan (8) Terlihat adanya hubungan antar sikap keberagamaan dengan kehidupan sosial sehingga perhatian terhadap kepentingan organisasi sosial keagamaan sudah berkembang.

\section{METODE}

Untuk memperoleh data, fakta, dan informasi yang akan menggambarkan dan menjelaskan permasalahan tentang upaya yang dilakukan dalam kegiatan Rohis untuk meningkatkan sikap keagamaan siswa, maka jenis penelitian ini adalah penelitian deskriptif.

Prosedur pemecahan masalah pada penelitian deskriptif adalah dengan cara menggambarkan objek penelitian pada saat sekaran berdasarkan fakta-fakta sebagaimana adanya, kemudian dianalisis dan diinterpretasikan, bentuknya dapat berupa survei dan studi perkembangan (Sofian, 2013 : 8).

Adapun lokasi dari penelitian ini adalah di SMK Ibnu Taimiyah penelitian ini dilaksanakan selama 6 bulan ( Juni sampai dengan November) 2016.

Pada penelitian ini yang menjadi subjek penelitian adalah pengurus dan anggota Rohis SMK Ibnu Taimiyah. Sedangkan objek penelitian ini adalah upaya meningkatkan sikap keagamaan siswa melalui kegiatan ekstrakurikuler rohis SMK Ibnu Taimiyah.

Populasi adalah daerah dan semua obyek yang dijadikan sasaran penelitian. Dalam hal ini populasi adalah keseluruhan subjek penelitian (Suharsimi Arikunto, 2002 : 108).
Dalam penelitian ini populasi adalah pengurus dan anggota Rohis di SMK Ibnu Taimiyah yang berjumlah 30 orang, dan karena populasi tidak lebih dari 100 orang, maka semua populasi dijadikan sampel yaitu 30 orang.

Adapun teknik pengumpulan data terdiri dari: (1) Observasi. Observasi atau pengamatan langsung adalah kegiatan pengumpulan data dengan melakukan penelitian langsung terhadap kondisi lingkungan objek penelitian yang mendukung kegiatan penelitian, sehingga didapat gambaran secara jelas tentang kondisi objek penelitian tersebut (Syofian, 2013 : 19). Observasi dilakukan peneliti disekolah khususnya pada kegiatan Rohis yang dilakukan; dan (2) Metode wawancara. Wawancara merupakan teknik pengumpulan data yang digunakan peneliti untuk mendapatkan keterangan lisan. Wawancara adalah proses memperoleh keteranagan untuk tujuan penelitian dengan cara tanya jawab sambil bertatap muka antara pewawancara dan orang yang diwawancarai dengan atau tanpa pedoman (Burhan, 2011 : 111). Wawancara ini ditunjukkan kepada guru pembimbing Rohis guna mengetahui upaya-upaya apa saja yang dilakukan Rohis dalam meningkatkan sikap keberagamaan siswa SMK Ibnu Taymiah; (3) Dokumentasi. Selain observasi dan wawancara, peneliti juga akan menggunakan berbagai dokumen dalam menjawab pertanyaan terarah. Metode ini digunakan untuk mendapatkan data tentang jumlah pegawai, murid, kelas, labotorium dan hal - hal lain yang berhubungan dengan penelitian ini, seperti keadaan guru, kepala sekolah, latar belakang atau sejarah berdirinya SMK Ibnu Taymiah; dan (4) Angket (Kuesioner). Kuesioner adalah suatu teknik pengumpulan informasi yang memungkinkan analisis mempelajari sikap-sikap, keyakinan, 
perilaku, dan karakteristik beberapa orang utama di dalam organisasi yang bisa terpengaruh oleh sistem yang diajukan atau oleh sistem yang sudah ada. Dengan menggunakan teknik ini, pengumpulan data sebagai data penelitian jauh lebih praktis, menghemat waktu dan tenaga, tidak memerlukan kehadiran peneliti, dapat dibagikan serempak kepada semua responden (Syofian, $2013: 21$ ).

\section{HASIL DAN PEMBAHASAN}

\section{Gambaran Umum SMK Ibnu Taimiyah Pekanbaru}

SMK Ibnu Taimiyah mulanya bernama SMEA Ibnu Taimiyah, berdiri. Pada tahun 1990 di Pekanbaru. Berdasarkan ketentuan bahwa sekolah swasta harus dibina oleh yayasan, maka pada tahun 1984 dibentuklah yayasan yang bertanggung jawab yang membina SMK IBNU TAIMIYAH, yang bernama YAYASAN ZAMRAD yang berdomesili di Jalan Hangtuah. ZAMRAD adalah nama donator/penyumbang lahan bangunan pertama berdirinya yayasan zamrad beserta gedung SMEA Ibnu Taimiyah dan Prof. Dr. H. Muchtar Ahmad, M,Sc yang ditunjuk serta dipercaya oleh Zamrad pada waktu itu sampai sekarang sebagai ketua yayasan ini.

SMK Ibnu Taimiyah berdiri diatas lahan seluas \pm 1 ( satu ) Hektar yang memiliki gedung permanen berlantai 3, terletak dilokasi yang amat strategis dengan lingkungan yang asri yang nyaman untuk ketenangan belajar dijalan Hang Tuah ( Jalan Angkatan 66 N0. 63 Rejosari Kota Pekanbaru ) lebih kurang 3,5 KM dari pusat kota Pekanbaru.

Kini SMK Ibnu Taimiyah semakin maju seiring dengan perkembangan zaman, dulu pertama sekolah ini berdiri hanya memiliki dua program studi yakni akuntansi dan Administrasi
Perkantoran dangan status akreditasi di Akui, kenyataannya sekarang program studi telah bertambah program Studi Penjualan, Teknik Computer dan Jaringan dan Teknik Multimedia.

Adapun visi SMK Ibnu Taimiyah Pekanbaru, yaitu: Menjadikan SMK Ibnu Taimiyah yang terbaik dalam bidang ekonomi dan teknologi informasi dalam menghasilkan lulusan terampil yang bermutu, efesien dan mampu memberikan pelayanan utama mulai 2015 . Sedangkan Misi SMK Ibnu Taimiyah Pekanbaru, yaitu: : Mengembangkan mutu sumber daya manusia terampil sehingga dapat memasuki pekerjaan bidang ekonomi dan teknologi informasi. Dengan indikator, yaitu: (a) Meningkatkan kemampuan profesionalisme guru-guru; (b) Melaksanakan KBM yang efektif sehingga siswa dapat berkembang secara optimal; (c) Pengalaman nilainilai ke-islaman dalam kehidupan warga sekolah; (d) Menata administrasi, meningkatkan dalam kehidupan warga sekolah; (e) Memberikan bimbingan.

SMK Ibnu Taimiyah memiliki bangunan yang representatif dengan ruangan-ruangan belajar serta ruanganruangan penunjang dengan ukuran standar juga infrastruktur yang mamadai dan lingkungan yang nyaman, kondisi ini sangat mendukung terhadap tujuan yang diharapkan.

\section{Rohis SMK Ibnu Taimiyah Pekanbaru Sejarah Rohis SMK Ibnu Taimiyah Pekanbaru}

Rohis SMK Ibnu Taimiyah Pekanbaru pada awalnya hanyalah merupakan perkumpulan kecil beberapa orang siswa yang berdiskusi tentang ajaran agama islam dan ingin memperdalam keyakinannya. Kegiatan yang dilakukan hanya sebatas sharing/ berdiskusi tentang hal-hal yang 
mereka kurang pahami dalam bergaul yang benar menurut islam. Seiring berjalannya waktu, melihat begitu antusiasnya siswa memperbaiki diri dalam pergaulan, maka guru agama islam pada saat itu sangat mendukung kegiatan yang dilakukan siswa tersebut.

Kegiatan pun semakin berkembang, tidak hanya mempelajari cara bergaul yang baik, mereka juga mempelajari ilmu tajwid, menyempurnakan sholat wajib dan sunnah, membahas tentang sejarah islam, dan lain-lain. Melihat keseriusan inilah akhirnya pada tahun 1999 organisasi Rohis resmi dibentuk sebagai wadah untuk meningkatkan pemahaman siswa dibidang agama islam.

\section{Kegiatan Rohis}

Adapun kegiatan harian organisasi rohis meliputi: (1) Melaksanakan sholat dzuhur berjama'ah; dan

Mendiskusikan masalah-masalah keagamaan. Sedangkan kegiatan mingguan organisasi rohis meliputi: (1) Mengadakan mentoring;

Mengadakan kajian islam; (3)

Mengumpulkan uang kas;

Mengadakan sharing (tanya jawab); (5) Membuat edaran mingguan berupa mading; (6) Mengumpulkan infaq dan sadaqah; (7) Ceramah agama setiap minggu ke- 1 dan ke- 4; dan (8) Yasinan setiap minggu ke- 2 dan ke- 3 .

Sedangkan kegiatan bulanan organisasi rohis seperti mengadakan perlombaan seperti lomba cerdas cermat, lomba sholat jenazah, dll.
Sedangkan kegiantan tahunannya meliputi: (1) Mengadakan open house untuk siswa baru; (2) Membantu OSIS dalam memperingati Hari Besar Agama Islam seperti : Maulid Nabi Muhammad SAW, Isra' Mi'raj, dan 1 Muharam; (3) Mengadakan kegiatan pada bulan suci Ramadhan; dan (4) Melaksanakan Latihan Dasar Kepemimpinan Rohis (LDKR).

\section{Hasil Penelitian}

Untuk mengetahui hasil dari penelitian, maka penulis memberikan angket kepada 30 siswa yang mengikuti kegiatan Rohis di SMK Ibnu Taimiyah Pekanbaru, serta wawancara kepada pembina Rohis yang kemudian dianalisa untuk mengetahui seberapa berperannya ekstrakurikuler Rohis dalam meningkatkan sikap keagamaan siswa. Hasil jawaban dari 30 responden terhadap sikap keagamaan kemudian dianalisa oleh penulis dengan menggunakan jumlah persentase jawaban, untuk lebih rincinya dapat dilihat pada lampiran 6 .

Berdasarkan data yang telah dikumpulkan, diperoleh hasil bahwa responden yang menjawab "selalu" berjumlah 208 atau 52\%, yang menjawab "sering" sebanyak 116 atau $29 \%$, kemudian disusul dengan jawaban "netral" sebanyak 26 atau 6,5 \%, selanjutnya yang menjawab "kadangkadang" sebanyak 25 atau 6,25\%, dan yang menjawab "tidak pernah" sebanyak 25 atau 6,25 \%.

Tabel 1 : Rekapitulasi Jawaban Responden Terhadap Angket

\begin{tabular}{|c|c|c|c|c|c|c|c|c|c|c|c|c|}
\hline \multirow{3}{*}{ NO } & \multicolumn{10}{|c|}{ ALTERNATIF JAWABAN } & \multirow{2}{*}{\multicolumn{2}{|c|}{ JUMLAH }} \\
\hline & \multicolumn{2}{|c|}{ A } & \multicolumn{2}{|c|}{ B } & \multicolumn{2}{|c|}{ C } & \multicolumn{2}{|c|}{ D } & \multicolumn{2}{|c|}{$\mathbf{E}$} & & \\
\hline & $\mathbf{F}$ & $\mathbf{P}$ & $\mathbf{F}$ & $\mathbf{P}$ & $\mathbf{F}$ & $\mathbf{P}$ & $\mathbf{F}$ & $\mathbf{P}$ & $\mathbf{F}$ & $\mathbf{P}$ & $\mathbf{F}$ & $\mathbf{P}$ \\
\hline $\mathbf{1}$ & 10 & 50 & 6 & 30 & 1 & 5 & 1 & 5 & 2 & 10 & 20 & 100 \\
\hline 2 & 17 & 85 & 0 & 0 & 0 & 0 & 2 & 10 & 1 & 5 & 20 & 100 \\
\hline
\end{tabular}




\begin{tabular}{ccccccccccccc}
\hline $\mathbf{3}$ & 9 & 45 & 7 & 35 & 1 & 5 & 2 & 10 & 1 & 5 & 20 & 100 \\
\hline $\mathbf{4}$ & 9 & 45 & 8 & 40 & 0 & 0 & 2 & 10 & 1 & 5 & 20 & 100 \\
\hline $\mathbf{5}$ & 9 & 45 & 8 & 40 & 1 & 5 & 1 & 5 & 1 & 5 & 20 & 100 \\
\hline $\mathbf{6}$ & 8 & 40 & 6 & 30 & 4 & 20 & 1 & 5 & 1 & 5 & 20 & 100 \\
\hline $\mathbf{7}$ & 11 & 55 & 5 & 25 & 2 & 10 & 1 & 5 & 1 & 5 & 20 & 100 \\
\hline $\mathbf{8}$ & 8 & 40 & 7 & 35 & 3 & 15 & 1 & 5 & 1 & 5 & 20 & 100 \\
\hline $\mathbf{9}$ & 5 & 25 & 11 & 55 & 2 & 10 & 1 & 5 & 1 & 5 & 20 & 100 \\
\hline $\mathbf{1 0}$ & 0 & 0 & 16 & 80 & 2 & 10 & 1 & 5 & 1 & 5 & 20 & 100 \\
\hline $\mathbf{1 1}$ & 8 & 40 & 7 & 35 & 3 & 15 & 1 & 5 & 1 & 5 & 20 & 100 \\
\hline $\mathbf{1 2}$ & 6 & 30 & 9 & 45 & 3 & 15 & 1 & 5 & 1 & 5 & 20 & 100 \\
\hline $\mathbf{1 3}$ & 12 & 60 & 4 & 20 & 2 & 10 & 1 & 5 & 1 & 5 & 20 & 100 \\
\hline $\mathbf{1 4}$ & 9 & 44 & 7 & 35 & 2 & 10 & 1 & 5 & 1 & 5 & 20 & 100 \\
\hline $\mathbf{1 5}$ & 9 & 45 & 8 & 40 & 0 & 0 & 2 & 10 & 1 & 5 & 20 & 100 \\
\hline $\mathbf{1 6}$ & 15 & 75 & 2 & 10 & 0 & 0 & 2 & 10 & 1 & 5 & 20 & 100 \\
\hline $\mathbf{1 7}$ & 16 & 80 & 1 & 5 & 0 & 0 & 1 & 5 & 2 & 10 & 20 & 100 \\
\hline $\mathbf{1 8}$ & 17 & 85 & 0 & 0 & 0 & 0 & 1 & 5 & 2 & 10 & 20 & 100 \\
\hline $\mathbf{1 9}$ & 13 & 65 & 4 & 20 & 0 & 0 & 1 & 5 & 2 & 10 & 20 & 100 \\
\hline $\mathbf{2 0}$ & 17 & 85 & 0 & 0 & 0 & 0 & 1 & 5 & 2 & 10 & 20 & 100 \\
\hline JMLH & $\mathbf{2 0 8}$ & $\mathbf{1 0 3 9}$ & $\mathbf{1 1 6}$ & $\mathbf{5 8 0}$ & $\mathbf{2 6}$ & $\mathbf{1 3 0}$ & $\mathbf{2 5}$ & $\mathbf{1 2}$ & $\mathbf{2 5}$ & $\mathbf{1 2}$ & $\mathbf{4 0}$ & $\mathbf{2 0 0}$ \\
& & & & & & & & $\mathbf{5}$ & & $\mathbf{5}$ & $\mathbf{0}$ & $\mathbf{0}$ \\
\hline
\end{tabular}

Persentase dari rekapitulasi angket :

\begin{tabular}{llll} 
1. Untuk alternatif jawaban A & $=5 \times 208$ & & $=1040$ \\
2. Untuk alternatif jawaban B & $=4 \times 116$ & & $=464$ \\
3. Untuk alternatif jawaban C & $=3 \times 26$ & & $=78$ \\
4. Untuk alternatif jawaban D & $=2 \times 25$ & & $=50$ \\
5. Untuk alternatifjawaban A & $=1 \times 25$ & & $=25$ \\
\hline Nilai Jawaban $\quad=5 \times 400=2000$ & & $=1657$
\end{tabular}

Selanjutnya untuk mencari persentase guna melihat kategori pelaksanaan penilaian terhadap peningkatan sikap keagaamaan melalui ektrakurikuler Rohis di SMK Ibnu Taimiyah Pekanbaru maka digunakan rumus :

$$
\begin{aligned}
& P=\frac{F}{N} \times 100 \% \\
& P=\frac{1657}{2000} \times 100 \% \\
& P=0,8285 \times 100 \% \\
& P=82,85 \%
\end{aligned}
$$

\section{Pembahasan}

Sebagaimana kita ketahui bahwa kegiatan Rohis identik dengan kegiatan keagamaan, jadi dalam hal ini tidak semua siswa tertarik dengan kegiatan Rohis. Umumnya siswa yang mengikuti kegiatan Rohis adalah siswa yang mempunyai latar belakang keluarga agamis. Tetapi ada juga siswa yang mengikuti kegiatan ini karena tertarik dengan acara-acara Rohis yang pernah di adakan.

Sikap keberagamaan yang dikaji dalam penelitian ini meliputi pokokpokok ajaran Islam secara garis besar, yaitu : aqidah, ibadah, akhlak. Sikap keagamaan bermacam-macam nilainya tergantung pada pelaksanaan dari setiap individu. Hal ini tercermin pula dalam pendidikan nasional yaitu berkembangnya potensi peserta didik agar menjadi manusia yang beriman, 
bertakwa, kepada Tuhan Yang Maha Esa, berakhlak mulia, sehat, berilmu, cakap, kreatif, mandiri, dan menjadi warga negara yang demokratis serta bertanggungjawab.

Aqidah anggota Rohis SMK Ibnu Taimiyah Pekanbaru memiliki keyakinan yang kuat terhadap ajaran agama Islam dan yakin terhadap Allah SWT. Dari segi ibadah siswa juga tetap istiqomah dalam menjalankan ibadah wajib dan sunnah, terbukti dengan adanya pelaksanaan sholat berjamaah dan puasa sunnah. Untuk segi akhlak para siswa yang mengikuti kegiatan Rohis sangat baik. Hal ini dapat dilihat dari hormatnya para siswa terhadap guru, patuh terhadap orang tua, dan peduli terhadap teman sebaya yang mengalami kesulitan.

Berdasarkan hasil penelitian yang telah dipersentasekan serta dianalisis oleh penulis, diperoleh hasil persentase $82,85 \%$ dimana berada pada taraf "tinggi". Artinya sebagian besar upaya yang dilakukan untuk meningkatkan sikap keagamaan siswa melalui kegiatan ektrakurikuler Rohis di SMK Ibnu Taimiyah Pekanbaru memiliki peningkatan. Peningkatan sikap keagamaan dapat dilihat dari keseharian siswa setelah mengikuti kegiatan ekstrakurikuler Rohis.

\section{SIMPULAN}

Berdasarkan data penelitian baik dari penyajian data dan analisis data, maka dapat diambil kesimpulkan bahwa upaya meningkatkan sikap keagamaan siswa melalui kegiatan ekstrakurikuler kerohanian Islam (Rohis) di SMK Ibnu Taimiyah Pekanbaru berada pada taraf "tinggi" dengan hasil persentase angket sebesar $82,85 \%$ karena berada diantara 76 - 85 $\%$. Artinya, upaya yang dilakukan untuk meningkatkan sikap keberagamaan siswa melalui kegiatan ekstrakurikuler
Rohis berhasil, hal ini dapat dilihat dari hasil persentase penelitian yang menunjukkan bahwa sekitar 82,85\% siswa telah melaksanakan kegiatan Rohis dengan baik dan memberikan efek positif terhadap kehidupan seharihari dalam peningkatan sikap keberagamaan siswa.

Adapun indikator penelitian ini meningkatkan sikap keberagamaan siswa melalui kegiatan Rohis di SMK Ibnu Taimiyah Pekanbaru adalah: (a) Menerima kebenaran agama berdasarkan pertimbangan pemikiran yang matang, bukan sekedar ikutikutan; (b) Cenderung bersifat realitas, sehinggga norma-norma agama lebih banyak diaplikasikan dalam sikap dan tingkah laku; (c) Bersikap positif terhadap ajaran dan norma-norma agama, dan berusaha untuk mempelajari dan memperdalam pemahaman keagamaan; (d) Tingkat ketaatan beragama didasarkan atas pertimbangan dan tanggung jawab diri hingga sikap keberagamaan merupakan realisasi dari sikap hidup; (e) Bersikap lebih terbuka dan wawasan yang lebih luas; (f) Bersikap lebih kritis terhadap materi ajaran agama sehingga kemantapan beragama selain didasarkan atas pertimbangan pikiran, juga didasarkan atas pertimbangan hati nurani; (g) Sikap keberagamaan cenderung mengarah kepada tipe-tipe kepribadian masing-masing, sehingga terlihat adanya pengaruh kepribadian dalam menerima, memahami serta melaksanakan ajaran agama yang diyakininya; dan (h) Terlihat adanya hubungan antar sikap keberagamaan dengan kehidupan sosial sehingga perhatian terhadap kepentingan organisasi sosial keagamaan sudah berkembang. 


\section{DAFTAR RUJUKAN}

Adz-Dzaky, Handani Bajtan. 2002. Konseling dan Psikoterapi Islam. Yogyakarta: Fajar Pustaka Baru.

Alim, Muhammad. 2006. Pendidikan Agama Islam; Upaya Pembentukan Pemikiran dan Kepribadian Muslim. Bandung: PT. Remaja Rosdakarya.

Aqib, Zainal dan Sujak. 2011. Panduan dan Aplikasi Pendidikan Karakter. Bandung: YramaWidya.

Ardy Wiyani, Novan. 2012. Ilmu pendidikan Islam. Yogyakarta: Arruzz Media.

Arikunto, Suharsini. 2002. Prosedur Penelitian (Suatu Pendekatan Praktek). Jakarta: Rineka Cipta.

Azwar, Saifuddin. 1995. Sikap Manusia Teori dan Pengukurannya. Yogyakarta: Pustaka Pelajar.

Bungin, Burhan. 2011. Penelitian Kualitatif. Jakarta: Kencana.

Dairi, Rizal. 2010. Metodologi Penelitian. Pekanbaru: UIR Press.

Darajat, Zakiyah. 1994. Remaja, Harapan dan Tantangan. Jakarta: CV Ruhma.

Departemen Pendidikan Nasional. 2008. Kamus Besar Bahasa Indonesia Pusat Bahasa. Jakarta: Gramedia.

Emzir. 2012. Metodologi Penelitian Kualitatif Analisis Data. Jakarta: Rajawali Pers.

Fidianti, Afdiah. 2009. Peran Kegiatan "Sie Kerohanian Islam (Rohis) Dalam Upaya Meningkatkan Perilaku Keberagamaan Siswa SMA Negeri I Sidoarjo. Skripsi. Malang: UIN Maulana Malik Ibrahim Malang, Malang.

Hanafi. 2014. Dasar-dasar Psikologo Agama. Pekanbaru: Lembaga Penelitian dan Pengabdian Kepada Masyarakat Universitas Islam Negeri Sultan Syarif Kasim Riau.

https:/ / id.wikipedia.org/ wiki/ Rohani I slam\#Kegiatan. Diakses 5 April 2016. Pukul 11.37 WIB.
Jalaluddin. 2008. Psikologi Agama (Memahami Perilaku Keagamaan Dengan Mengaplikasikan PrinsipPrinsip Psikologi). Jakarta: Raja Grafindo Persada.

Muhaimin. 2009. Perkembangan Kurikulum Pendidikan Agama Islam di Sekolah, Madrasah dan Perguruan Tinggi. Jakarta: PT.Raja Grafindo.

Muhammad, Abubakar. 2004. Pembinaan Manusia Dalam Islam. Surabaya: Al Ikhlas.

Muri Yusuf, Metodologi Penelitian, UNP Press ,Padang, 2005.

Mushbihah Rodliyatun, Peranan Pembina Kegiatan Ekstrakurikuler Rohani Islam (rohis) Dalam Meningkatkan Sikap Keberagamaan Siswa Di SMK Salatiga. Salatiga : Program Pascasarjana Sekolah Tinggi Agama Islam Negeri Salatiga, 2013.

Novian, Peranan Peranan Rohani Islam Sekolah (Rohis) Dalam Pembinaan Akhlak Siswa Di Sekolah Menengah Atas Negeri 2 Tebing Tinggi Kabupaten Kepulauan Meranti, Universitas Islam Riau, Pekanbaru, 2013.

Purwanto, Ngalim. 1992. Prinsip Prinsip dan teknik Evaluasi Pendidikan. Bandung: Remaja Rosdakarya.

Riduwan dan Sunarto. 2011. Pengantar Statistik untuk Penelitian Pendidikan, Sosial, Ekonomi, Komunikasi, dan Bisnis. Bamdung: Alfabeta.

Siregar, Syofian. 2013. Metode penelitian kuantitatif. Jakarta: Kencana.

Slameto. 1995. Belajar dan FaktorFaktor yang Mempengaruhinya. Jakarta: PT. Rineka Cipta.

Subandi. 2013. Psikologi Agama dan Kesehatan Mental. Pustaka Pelajar. 
